\title{
The implications of disconnectivity for the study of contemporary geomorphic processes
}

\author{
Olav SLAYMAKER ${ }^{1^{*}}$ \\ ${ }^{1}$ Department of Geography, University of British Columbia, Vancouver, British Columbia, Canada \\ Received 26 September 2017; Revised 5 October 2017; Accepted 6 October 2017 \\ *Correspondence to: Olav SLAYMAKER, e-mail: olav.slaymaker@ubc.ca
}

\begin{abstract}
The emphasis on the understanding of contemporary geomorphic processes that has dominated Anglophone geomorphological literature over the past 50 years has seen huge progress but also some set-backs. We now have reliable measurements of mean rates of operation of all subaerial processes responsible for modification of landforms and landscapes and have made good progress in estimating the role of human activities as compared with "natural" processes. Some limited progress has been achieved in understanding the scale problem but problems remain. Perhaps the single most surprising development has been the recognition of the ubiquity of disconnectivity in geomorphic systems, the need to calculate virtual velocities of whole geomorphic systems and the relevance of this understanding to the general spatio-temporal scale problem. We have always known that most geomorphic processes operate intermittently but we have continued to depend on models that imply that mass and energy move freely through geomorphic systems and that conservation of mass and energy occurrs uninterruptedly at all temporal and spatial scales.
\end{abstract}

KEYWORDS

Disconnectivity; connectivity; coupling; contemporary geomorphic processes

\section{Introduction}

During the period 1960-1990 measurement and description of contemporary geomorphological processes on synoptic to seasonal scales and the construction of first-order theories to generalize the phenomena were the dominant geomorphological studies (Schumm and Lichty, 1965; Church, 2010). This history is to a significant degree summarized in the pages of "Progress in Physical Geography" on subjects such as weathering; slope processes; soil erosion; river hydraulics, river morphology; karst; 
coastal and beach processes; wind effects and glaciation. Since 1990 dramatic changes have occurred. These changes were summarized by Church (2010) as (a) improved technologies for remote sensing and surveying of Earth's surface; (b) recognition that geomorphology is a "system science"; (c) the reintegration of tectonics into geomorphology; (d) development of absolute dating techniques; and (e) increasing recognition of the dominance of contemporary human modification of Earth's surface. Slaymaker (2009) focussed on the future needs of geomorphology: (a) the emergence of a broader philosophical basis; (b) clearer definition of the objects of geomorphological study; and (c) an integration of geomorphological geohistory and process geomorphology. Slaymaker's discussion looks forward to a future geomorphology whereas Church's presentation is a real world perspective on the present trajectory of the field. But both approaches converge in predicting the necessity for geomorphologists to recognize that the
Anthropocene epoch requires new skills and intellectual perspectives.

Relief, climate, sea level and human activities have been identified as primary drivers of global terrestrial processes over longer time scales (Slaymaker et al., 2009); but over centennial time scales relief and sea level can for most purposes be regarded as constant, and climate and human activities become the global drivers of change. Hence the contemporary emphasis on global hydroclimate change which should be tempered with an equal emphasis on the growing societal impact on land.

When attention turns to regional and local scale changes over contemporary time scales the assignment of drivers is more complex and is sometimes impossible. The spatiotemporal scale problem and associated problems of coupling, connectivity, disconnectivity and complexity have become prominent. This recent discussion in so far as it affects mountain environments has been summarized (Slaymaker and Embleton-Hamann, 2009).

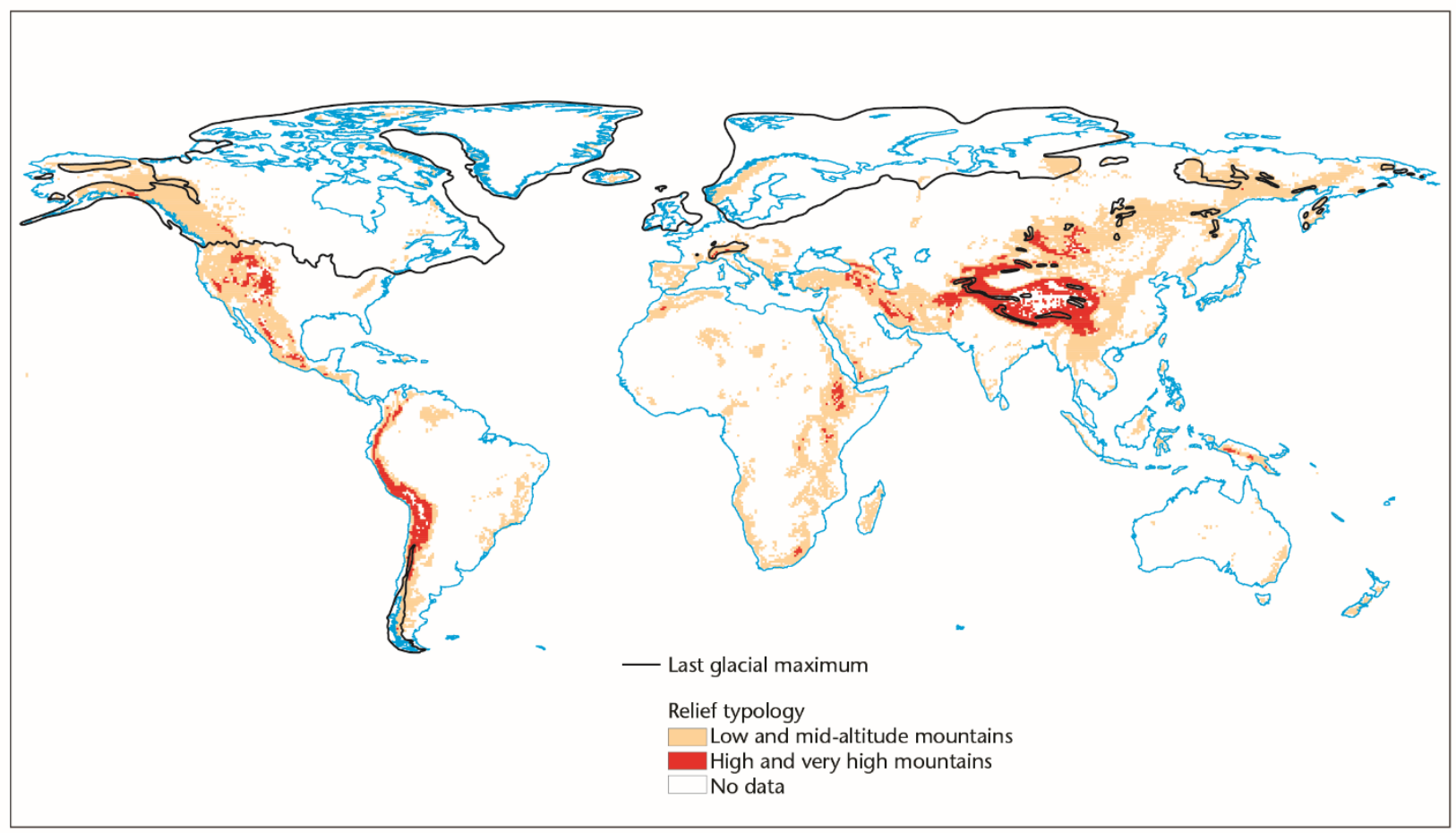

Figure 1 Map showing the global distribution of mountains (after Church and Slaymaker, 2016), with the extent of Late Pleistocene glaciation overprinted 


\section{Mountains and the high energy condition}

High mountains, in view of their steepness and severe weather, are commonly reckoned to experience the highest rates of sediment mobilization on Earth. Glacier and or ice sheet cover in the past or at present complicates the relationship (Fig. 1).

It is an interesting question however to ask what becomes of sediment mobilized on steep mountain slopes. Much of it goes back into storage in slope base colluvium and alluvial fans, notable features of all the world's mountain ranges. The reasoning underlying this belief is that these regions are subject to the largest potential energy gradients on Earth's terrestrial surface. In fact, the sediment yield of mountainous areas is remarkably variable, stemming from the variation of geology, history, physiography and climate. Today, an increasingly important element of mountain history is the growing dominance of human settlement in mountain landscapes, especially in Asia, Africa, South America and Europe. These populations are not only exposed to the hazards presented by sediment fluxes in the mountains, but their manipulations of the land surface affect the condition and tempo of the fluxes down valley.

The high energy condition has long been associated with the highest rates of energy expenditure and continuity of mass and energy flows has been assumed (Caine, 1974). It was unquestioned that the highest mountains were the sites of the greatest geomorphic work as illustrated, for example, in Fig. 2. That figure relies on a simplistic model from Summerfield and Hulton (1994) in which

$$
\text { Denudation Rate }=7.21 \times e^{0.0015 \times \text { elevation }}
$$

where Denudation rate is expressed in $\mathrm{m} \times \mathrm{Ma}^{-1}$ and elevation is in meters.

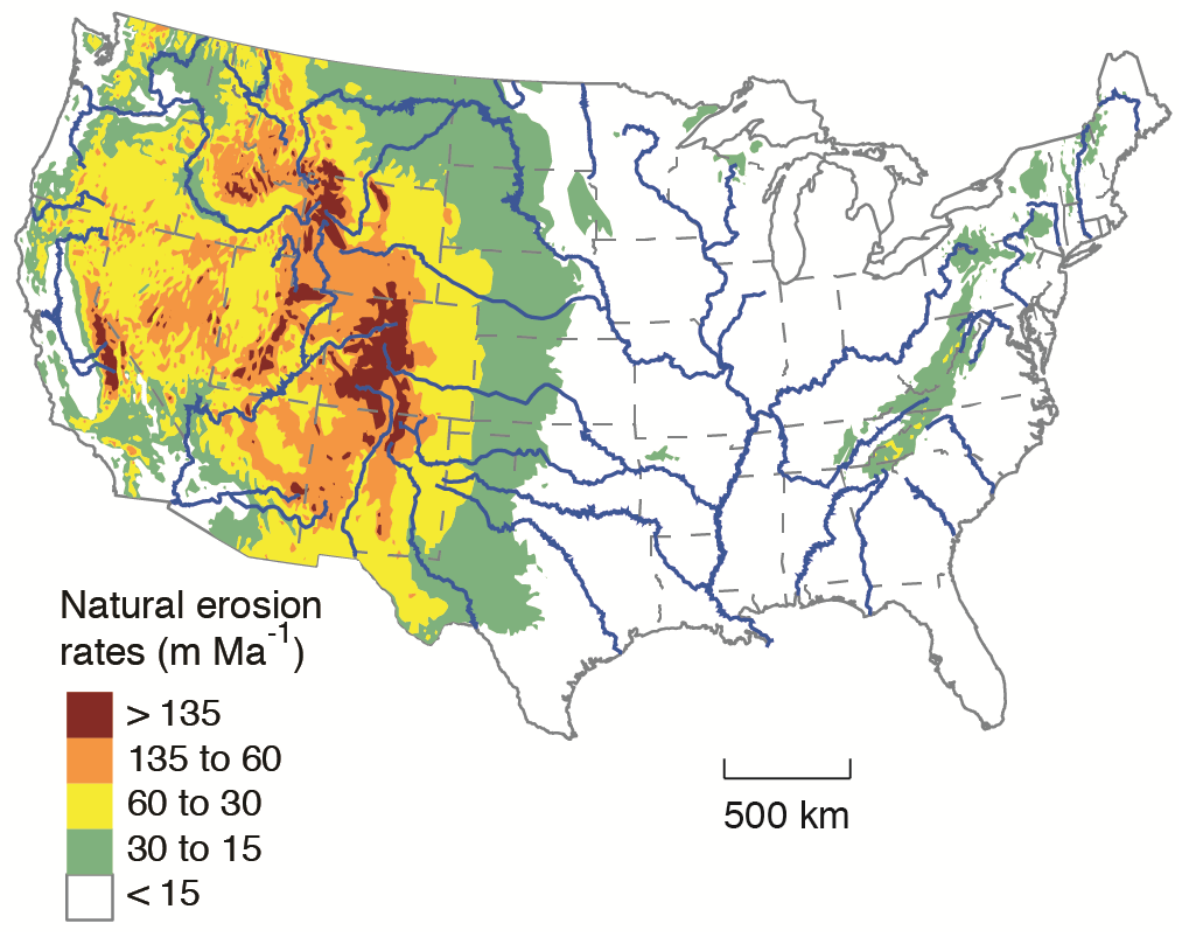

Figure 2 Estimates of average natural erosion rates inferred from GTOPO30 area-elevation data and global fluvial erosion-elevation relations from Summerfield and Hulton (1994) (from Wilkinson and McElroy, 2007). Units are in metres of denudation per million years 
The implication of this model is that net annual erosion for large drainage basins $\left(>500,000 \mathrm{~km}^{2}\right)$ increases by $0.15 \%$ for every meter increase in maximum elevation. In other words, Fig. 2 is basically a hypsometric map.

Recent empirical data suggest that decoupling is more common than coupling even in the highest mountains. There are self-evident discontinuities in sediment production, transport and deposition (Fort et al., 2009; Hewitt, 2009; Hewitt et al., 2011). Geochemical surface lowering processes are distributed throughout the mountains but extreme landslides, for example, are highly localized (Korup et al., 2007; Waller et al., 2012; Slaymaker et al., 2017). We now commonly ask the question "Where in the mountain landscape does the greatest amount of denudation occur?" rather than assuming that the highest and steepest slopes provide the answer.

The special emphasis on high mountain geomorphology (Holtmeier, 2015) was that the high mountain zone was unique, in part because of its high energy environment. Increasingly, evidence shows that work in the landscape is maximized in moderate relief mountains (Slaymaker, 2013), in some cases even in low relief regions (Kirchner and Ferrier, 2013; Willenbring et al., 2013).

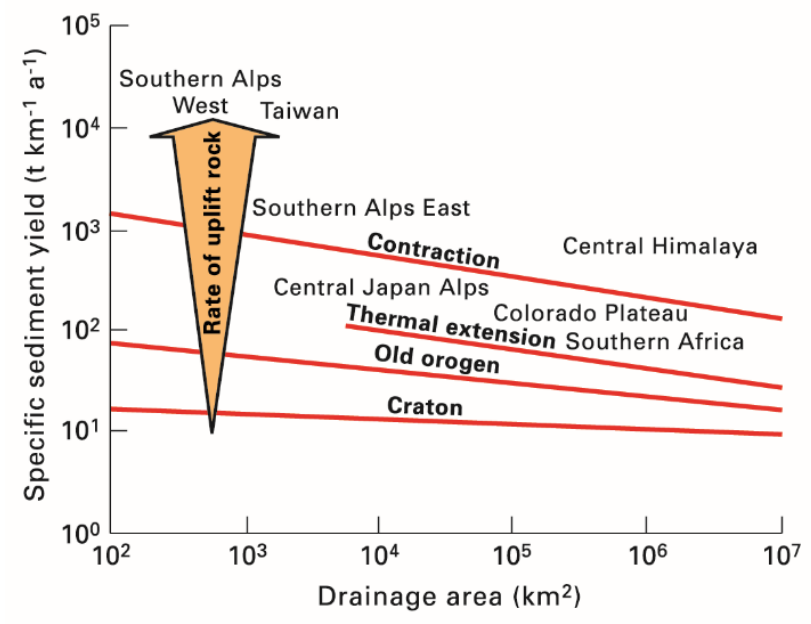

Figure 3 Specific sediment yield versus drainage area by tectonic setting (from Hovius, 1998)

Of great interest is the relation between tectonics and sediment yield as calculated by Hovius
(1998; Fig. 3). He insisted that sediment yield equations should always factor in the role of tectonic activity. Scaled for drainage basin area, sediment yields increase through almost five orders of magnitude from tectonic cratons to contractional mountains. He noted that tectonically active mountain belts not only provide relief to drive erosion processes but also combine high regolith loss with rapid uplift of new bedrock into the weathering zone to continually refresh the erosion processes and maintain high sediment yield (Korup et al., 2014).

\section{Sediment cascades}

The study of sediment cascades from source to sink has become a central theme in mountain process geomorphology over the past three decades (Dietrich et al., 1982). A major statement on the importance of sediment routing systems from source to sink is found in Allen (2008). When thinking about coupling and decoupling of slopes and channels the identification of preferred pathways for sediment fluxes is essential (EmbletonHamann and Slaymaker, 2006) and the use of sediment budgets is recommended. But the comparative advantage of using such a model is frequently ignored by the exclusion of one or more components of the sediment-solutes-nutrients continuum. Sediment budgets incorporating sediment, dissolved solids and nutrient fluxes are scarce, but Filippelli et al. (2010) is an instructive example. Magnitude-frequency considerations in sediment budgets for arctic and sub-arctic catchments are also incorporated in Beylich and Kneisel (2009).

Chemical components of sediment budgets operate on different time scales from the clastics. One way of avoiding the problem of partial sediment budgets is to choose geomorphic locations in which clastic sediments dominate over all other mass fluxes. Examples such as sediment flux on a reach by reach assessment used to establish big picture sediment flux (Hassan et al., 2011); and studies of rivers in which sediment flux is dominantly clastic (Yellow River, Miao, 2010) and upland gravel bed rivers (Raven et al., 2010). 
Schiefer et al. (2010) provided a rare example of total sediment flux accounting. Holocene and contemporary sediment budgets for a $324 \mathrm{~km}^{2}$ cordilleran catchment have been estimated with the aid of seismic records, dated cores and sections in lake and alluvial fill sediments at Chilliwack Lake in the North Cascade Mountains, British Columbia (Tunnicliffe et al., 2012a; 2012b).

Use of the concept of process domains is popular in North America to demonstrate the connection between morphology and process. Examples of process domain influence on river long profiles and channel reach morphology (Brardinoni and Hassan, 2007) and the organization of process domains as part of the legacy of glaciation in Puget Sound (Collins and Montgomery, 2011) demonstrate the flexibility of this approach.

\section{Coupling}

Coupling in general is the extent to which surface and subsurface channels and slopes are physically connected (Harvey, 2002). More specifically, coupling considers the variety of ways in which water, sediment and dissolved solids move through a system or are obstructed from moving between source areas and the river system. Where hillslopes and river channels are tightly coupled there is a continuous or semi-continuous flow of water, sediment and dissolved solids from slopes to channels. Water and dissolved solids commonly follow preferred pathways from headwaters to the outlet of a river basin whereas clastic sediments accumulate at preferred locations in the basin, such as breaks of slope or lake basins. The rate at which morphological changes propagate through the system (or virtual velocity) depends directly on the degree of coupling. Tight coupling implies relatively rapid change; decoupling implies slow change. This coupling model is consistent with the sediment cascade model by which the rate and nature of movement of sediments from source to sink and the associated rates of denudation of the mountain landscape can be estimated by determining all components of a sediment budget.
Degrees of coupling are recognized in the literature as, for example, discontinuities in mountain streams (Lu and Richards, 2008). Geomorphic coupling between hillslopes and channels has been documented in the Swiss Alps (Savi et al., 2013) and coupling of landslides and rivers has been identified in the Carpathian and Sudete Mountains (Malgorzata et al., 2015)

The various morphological elements in the glacierized Lillooet-Harrison River basin $\left(7,870 \mathrm{~km}^{2}\right)$ in the Pacific Ranges of the Coast Mountains of British Columbia, have been mapped according to the extent of their coupling to the mainstream river (Slaymaker et al., 2017). Three examples focus on ridge tops, hillslopes subject to infrequent large mass movements and debris avalanches:

(a) Ridge tops and accordant summits with low local relief are coupled to the valley primarily through water and dissolved solids moving along sub-surface pathways. Clastic sediments are commonly decoupled on ridge tops.

(b) Hillslopes subject to infrequent large mass movements are episodically coupled

(c) Debris avalanches and debris flow channels directly couple hillslopes with valley bottom (Fig. 4).

The temporal episodic coupling and the spatial decoupling of individual processes guarantees an overall complex response to disturbance. Jefferson et al. (2010), working on the western slopes of the Cascade Range in Oregon, USA, have partitioned hydrologic flowpaths between surface and subsurface flow. They have proposed that landscape evolution in basalt terrains is entirely constrained by the coupling and decoupling of surface and subsurface flow (Jefferson et al., 2010)

Young basalt terrains are highly permeable, allowing one to examine timescales and processes of geomorphic evolution via surface and subsurface flow. On Holocene and late Pleistocene lava landscapes, groundwater systems transmit most of the recharge to large springs with very steady hydrographs. In watersheds $>1$ million years old, springs are absent, and well-developed drainage networks fed by shallow subsurface stormflow produce flashy hydrographs. 


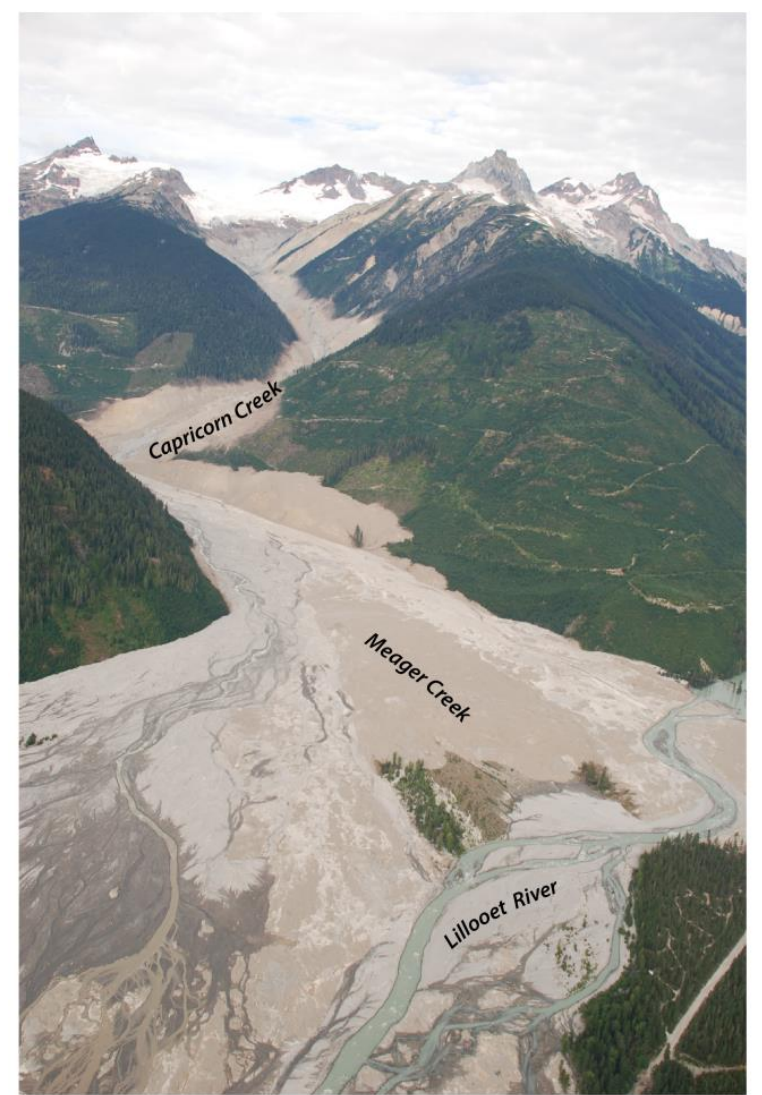

Figure 4 The 2010 Capricorn debris avalanche in the Mount Meager Volcanic Complex, Pacific Ranges, Coast Mountains, British Columbia (oblique photograph taken on August 29, 2010 by John Clague)

\section{Connectivity and disconnectivity}

One important recent development in understanding of mountain geomorphology is the idea of connectivity, a concept that has been explored by Fryirs and Brierley (2009; 2013). Connectivity formed the central focus of the 2016 Binghamton Symposium (Wohl and Beckman, 2014). This idea clearly grows out of the idea of coupling, but it gives greater emphasis to the fact that most geomorphic systems, even mountain systems, are characterized more by decoupling than by coupling. The reason, self-evidently, is the lack of connectivity between the various components of the sediment cascade (Tunnicliffe and Church, 2011). Sediment yield in fluvially dominated mountains is systematically scaled in the landscape; that is to say there is a well defined relationship between drainage basin area and specific sediment yield.
By contrast, in glaciated mountains, tectonically active mountains and mountains heavily perturbed by human activity the well-defined relationship between basin area and specific sediment yield ceases to hold because of different perturbations of sediment storage areas that produces multiple scaling (Church and Slaymaker, 2016). Not only is there a spatial discontinuity problem, but temporal discontinuity is equally important.

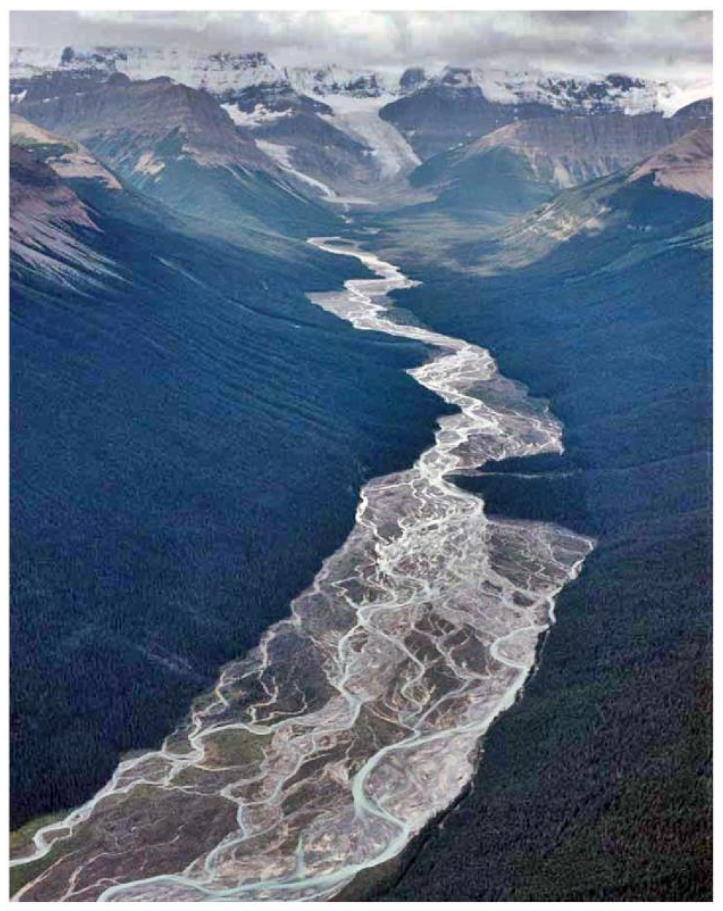

Figure 5 Connectivity from Mt. Alexandra, through Alexandra Glacier to the braided channel of the Alexandra River, Banff National Park, Alberta (Photo by Robert Sandford)

\section{Disconnectivity in independent process systems}

Each process system whether glacial, fluvial, glacial lake outburst flood or mass movement has its own internal disconnectivity issues as follows:

\subsection{Glaciers and Glacial lake outburst floods (GLOFS)}

The Mt. Alexandra-Alexandra Glacier-Alexandra River connectivity is exceptionally unbroken (Fig. 5). 
More commonly, the connectivity between glacial sediment production and downstream sediment fluxes is significantly reduced by the development of proglacial lakes and intermittent tributary debris flows.

Suspended and solute sediment fluxes from the proglacial zone of the retreating Obersulzbachkees glacier, Hohe Tauern, Austria are strongly controlled by the presence of proglacial lakes (Geilhausen et al., 2013). Three glacier basins in Norway have been shown to have totally different sediment budgets because overdeepened bedrock basins define the locations of proglacial lakes. Despite an expected increase in sediment yield from the glacier, little sediment will pass these lakes and downstream sediment delivery will be reduced markedly (Bogen et al., 2015).

Sandurs provide disconnectivity in space; the periodic nature of jokulhlaups produces disconnectivity over time. Jokulhlaups figure prominently in proglacial landscape change at Sólheimajökull in southern Iceland from 1960 to 2010. Changes in glacial meltwater runoff regimes, glacier terminus position, sediment supply and episodic events such as jökulhlaups are implicated.
Heckmann et al. (2016) have provided a valuable overview of the state of understanding of GLOFS.

\subsection{Mountain rivers}

Kasprzak and Migon (2015) commented on the importance of fluvial erosion by comparison with mass movement in the Sudetes Mountains in Poland. In providing an overview of morphodynamics of steep-mountain channels (Brardinoni et al., 2015), the complexity of the behaviours of coarse and fine sediment plus large organic debris in steep mountain channels is illustrated from research in Canada, Austria and Italy. In the tectonically active Chugach Mountains in Alaska the rates of hillslope erosion are an order of magnitude below the rate of glacial sediment export because the very high landslide rates are periodic and localized and the very high glacifluvial sediment flux is continuous over time (Uhlmann et al., 2013). There is surprisingly little progress in incorporating the role of weathering in regional calculations of denudation in steep watersheds in spite of the recommendations by Church et al. (2006) for increased attention to this topic.

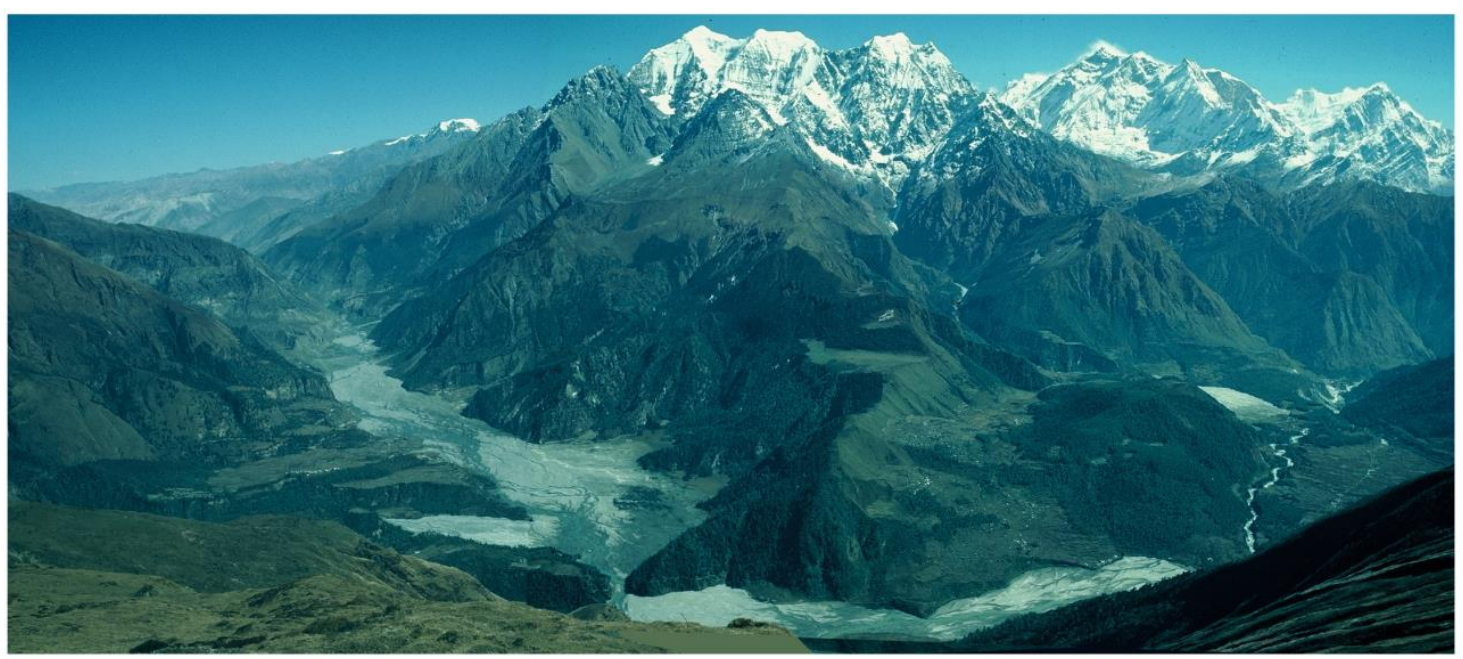

Figure 6 Disconnectivity created by the large, prehistoric Dhumpu-Kalopani rock avalanche in the Nepal Himalayas (photo by Monique Fort) (after Fort et al., 2010)

\subsection{Mass movement}

The intermittency of mass movement processes has generated the need to improvise specific new techniques of field analysis. For example, a multitemporal record of erosion (1963-2005) of a rock slope in the Swiss Alps identified slope failures that affect $70 \%$ of the study slope and produced an 
inventory of $\sim 2500$ failures ranging over 6 orders of magnitude in volume. Rockslides and rockfalls of high magnitude and relatively low frequency make up $99 \%$ of the total failure volume from highly fractured and weathered quartzites and are thus responsible for the high erosion rate (Scapozza et al., 2014).

Mass movement processes are all intermittent with the possible exception of soil and rock creep. Therefore it is not surprising that disconnectivity within mountain regions is the norm. Work in the Karakoram Himalayan region of Pakistan has produced some of the finest examples of disturbance regimes in which massive mass movements have generated disconnectivity over periods from centuries to millennia (Hewitt, 2009; Fort et al., 2010; Hewitt et al., 2011; Hewitt, 2014) (Fig. 6).

\subsection{Drainage systems}

Catastrophic rock failures are also discussed by Hewitt et al. (2008). Their distinctive morphology is commonly a legacy of past catastrophic events, consisting of partial obstructions by landslide barriers that "create a chronically fragmented drainage system" (Hewitt, 2006).

Mountain geomorphic processes can be envisaged as a cascade of disturbance processes that alter stream and riparian geosystems (Fig. 7). The affected stream and riparian landscape can be viewed through time as a network containing a shifting mosaic of disturbed patches. Linear zones of disturbance are created by the cascading geomorphic processes.
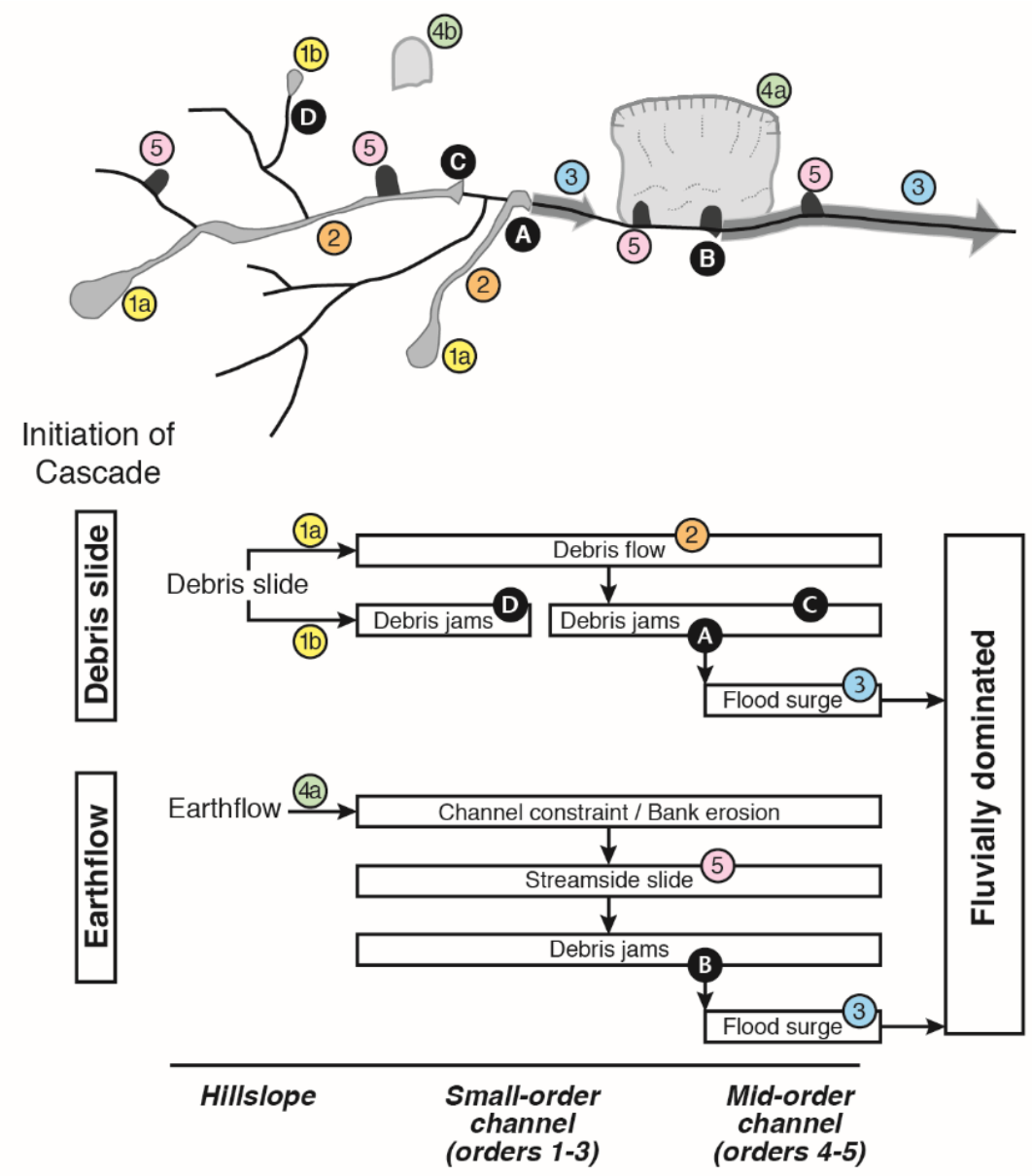

Figure 7 Disconnectivity within disturbance cascades: interaction among processes drainage system-wide (after Nakamura et al., 2000). Log and debris dams at sites A, B, C and D promote system resilience 
Ecological disturbances range in severity from effects of debris flows, which completely remove colluvium along steep, narrow low order channels to localized patches of trees toppled by floating logs along the margins of larger channels. Because disturbances by human activities have become so much more common land use changes can affect the frequency and spatial pattern of events and the quantity and size distribution of material removed (Slaymaker and Kovanen, 2017).However a welldeveloped network of stream and riparian systems may lend resilience in the face of major disturbances by providing widely distributed storage areas (Fig. 7).

The above two examples of watershed disturbance are end points of a spectrum that ranges from small, low order streams, typical of North America's forested mountains, to the huge rock avalanches of central Asia. Each is characterized by major disconnectivities that lend resilience to the landscape.

\section{Conclusion}

Recent research on mountain geomorphic systems has emphasized the importance of disturbances and disconnectivities by contrast with earlier work that identified coupling as a distinctive feature of mountain systems. Because disturbances caused by both mountain geomorphological processes and human activities produce disconnectivities in the landscape the recognition and analysis of these features has become of increasingly applied significance in watershed management.

\section{Acknowledgments}

The author acknowledges the generous assistance of John Clague, Monique Fort and Robert Sandford in making their photos available; he also acknowledges Eric Leinberger's excellent cartography.

\section{References}

Allen PA. 2008. From landscapes into geological history. Nature 451: 274-276.
Beylich A, Kneisel C. 2009. Sediment budget and relief development in Hrafndalur, sub-arctic oceanic eastern Iceland. Arctic, Antarctic and A/pine Research 41: 3-17.

Bogen J, Xu M, Kennie P. 2015. The impact of proglacial lakes on downstream sediment delivery in Norway. Earth Surface Processes and Landforms 40: 942-952.

Brardinoni F, Hassan MA. 2007. Glacially induced organization of channel reach morphology in mountain streams. Journal of Geophy sical Research 112 FO3013, doi: 10.1029/2006JF000741.

Brardinoni F, Mao L, Recking A, Rickenmann D, Turowski J. 2015. Morphodynamics of steep mountain channels. Earth Surface Processes and Landforms 40: 1560-1562.

Caine N. 1974. The geomorphic processes of the alpine environment. In: Ives JD, Barry RG, (eds.): Arctic and Alpine Environments. Methuen, London: 721-748.

Church M. 2010. The trajectory of geomorphology. Progress in Physical Geography 34: 265-286.

Church M, Slaymaker O. 2016. Signatures of sediment yield in the world's mountains. In: Mainali K, Sicroff S, (eds.): Jack D. Ives: Montologist. Festschrift for a Mountain Advocate. Himalayan Association for the Advancement of Science, Lalitpur, Nepal: 67-93.

Church M, Owens P, Petticrew E, Souch C, eds. 2006. Sediment and geochemical budgets. Geomorphology 79: 1-142.

Collins BD, Montgomery DR. 2011. The legacy of Pleistocene glaciation and the organization of lowland alluvial process domains in the Puget Sound region. Geomorphology 126: 174-185.

Dietrich WE, Dunne T, Humphrey NF, Reid LM. 1982. Construction of sediment budgets for drainage basins. In: Swanson FJ, Janda RJ, Dunne T, Swanston DN. (eds.): Sediment Budgets and Routing in Forested Drainage Basins. USDA Forest Service, Portland. General Technical Report PNW-141: 5-22.

Embleton-Hamann C, Slaymaker O. 2006. Classics in physical geography: Jackli $\mathrm{H}, 1957$. Progress in Physical Geography 30: 779-783.

Filippelli GM, Souch C, Horn SP, Newkirk D. 2010. The preColombian footprint on terrestrial nutrient cycling in Costa Rica: insights from phosphorus in a lake sediment record. Journal of Paleolimnology 43: 843-856.

Fort $M$, Cossart E, Deline P, Dzikowski M, Nicoud G, Ravanel L, Schoeneich P, Wassmer P. 2009. Geomorphic impacts of large and rapid mass movements: a review. Géomorphologie 15: 47-64.

Fort M, Cossart E, Arnaud-Fassetta G. 2010. Catastrophic landslides and sedimentary budgets. In: AlcantaraAyala I, Goudie AS. (eds.): Geomorphological Hazards and Disaster Prevention. Cambridge University Press, Cambridge: 75-95. 
Fryirs KA, Brierley GJ. 2009. Naturalness and place in river rehabilitation. Ecology and Society, 14-20. URL: http://www.ecologyandsociety.org/vol14/20.1

Fryirs KA, Brierley GJ. 2013. Geomorphic Analysis of River Systems: An Approach to Reading the Landscape. DOI: $10.1002 / 9781118305454 . c h 1$

Geilhausen M, Morche D, Otto J-C, Schrott L. 2013. Sediment discharge from the proglacial zone of a retreating alpine glacier. Zeitschrift fur Geomorphologie Supp. Band 57: 29-53.

Harvey A. 2002. Effective time scales of coupling within fluvial systems. Geomorphology 44: 175-201.

Hassan MA, Church M, Yan Y, Slaymaker O. 2010. Spatial and temporal variation of in-reach suspended sediment dynamics along the main stem of the Changjiang River. Water Resources Research 46, W11551, doi: 10.1029/2010WR009228, 2010.

Heckmann T, McColl S, Morche D. 2016. Retreating ice: research in proglacial areas matters. Earth Surface Processes and Landforms 41: 271-276.

Hewitt K. 2006. Disturbance regime landscapes: mountain drainage systems interrupted by large rock slides. Progress in Physical Geography 30: 365-393.

Hewitt K. 2009. Paraglacial rock slope failures, disturbance regimes and transitional landscapes, Upper Indus Basin, northern Pakistan. In: Knight J, Harrison S, (eds.): Periglacial and Paraglacial Processes and Environments. The Geological Society, London, Special Publications 320: 235-255.

Hewitt K. 2014. Glaciers of the Karakoram Himalaya. Springer International Publishing Switzerland.

Hewitt K, Clague JJ, Orwin JF. 2008. Legacies of catastrophic rock slope failures in mountain landscapes. Earth Science Reviews 87: 1-38.

Hewitt K, Clague JJ, Gosse J. 2011. Rock avalanches and the pace of late Quaternary development of river valleys in the Karakoram Himalaya. Geological Society of America Bulletin 123: 1836-1850.

Holtmeier F-K. 2015. Carl Troll in memoriam. Progress in Physical Geography 39: 554-565.

Hovius N. 1998. Controls on sediment supply by large rivers. In: Shanley KW, McCabe PJ, (eds), Relative Role of Eustasy, Climate and Tectonics in Continental Rocks. Society of Economic Paleontologists and Mineralogists, Tucson: 3-16

Jefferson A, Grant GE, Lewis SL, Lancaster ST. 2010. Coevolution of hydrology and topography on a basalt landscape in the Oregon Cascade Range, USA. Earth Surface Processes and Landforms 35: 803-816.

Kirchner JW, Ferrier KL. 2013. Mainly in the plain. Nature 495: 318-319.
Korup O, Clague JJ, Hermanns RL, Hewitt K, Strom AL, Weidinger JT. 2007. Giant landslides, topography and erosion. Earth and Planetary Science Letters 261: 578-589.

Korup O, Hayakawa Y, Cdilean AT, Matsushi Y, Saito H, Oguchi T, Matsuzaki H. 2014. Japan's sediment flux to the Pacific Ocean revisited. Earth Science Reviews 135: 1-16.

Lu H, Richards KS. 2008. Sediment delivery: new approaches to modelling a old problem. In: Rice SP, Roy AG, Rhoads B. (eds.): River Confluences, Tributaries and the Fluvial Network. John Wiley and Sons, Chichester: 337-366.

Malgorzata W, Malik I, Wojcicki K, Michalowicz P. 2015. Coupling between landslides and eroding stream channels reconstructed from spruce tree rings. Earth Surface Processes and Landforms 40: 293-312.

Miao C. 2010. Yellow River sediment. Progress in Physical Geography 34: 541-561.

Migon P, Kasprzak M. 2015. Pathways of geomorphic evolution of sandstone escarpments in the Góry Stołowe tableland (SW Poland) - Insights from LiDAR-based high-resolution DEM. Geomorphology DOI:10.1016/j.geomorph.2015.08.022.

Nakamura F, Swanson FJ, Wondzell SM. 2000. Disturbance regimes of stream and riparian systems: a disturbance-cascade perspective. Hydrological Processes 14: 2849-2860.

Raven EK, Lane SN, Bracken LJ. 2010. Understanding sediment transfer and morphological change for managing upland gravel bed rivers. Progress in Physical Geography 34: 23-45.

Savi S, Schneuwly-Bollschweiler M, Bommer-Denns B, Stoffel M, Schlunegger F. 2013. Geomorphic coupling between hillslopes and channels in the Swiss Alps. Earth Surface Processes and Landforms 38: 959-969.

Scapozza C, Lambiel C, Bozzini C, Mari S, Conedera M. 2014. Assessing rock glacier kinematics on three different time scales: a case study from the southern Swiss Alps. Earth Surface Processes and Landforms 39: 2056-2069.

Schiefer E, Hassan MA, Menounos B, Pelpola CP, Slaymaker O. 2010. Interdecadal patterns of total sediment yield from a montane catchment, southern Coast Mountains, British Columbia. Geomorphology 118: 207-212.

Schumm SA, Lichty RW. 1965. Time, space and causality in geomorphology. American Journal of Science 263: 110-119.

Slaymaker O. 2009. Proglacial, periglacial or paraglacial? In: Knight J, Harrison S. (eds.): Periglacial and Paraglacial Processes and Environments. The Geological Society, London, Special Publication 320: 71-84. 
Slaymaker O. 2012. Geomorphic change in Canada's temperate mountains. In: French HM, Slaymaker $\mathrm{O}$. (eds.): Changing Cold Environments: a Canadian Perspective. Wiley-Blackwell, Oxford, Chichester and Hoboken: 222-246.

Slaymaker O. 2013. Mountain environment changes in the Anthropocene epoch. Opera Corcontica 50: 107-118.

Slaymaker O, Embleton-Hamann C. 2009. Mountains. In: Slaymaker O, Spencer T, Embleton-Hamann C. (eds.): Geomorphology and Global Environmental Change, Cambridge University Press, Cambridge: 37-70.

Slaymaker O, Kovanen DJ. 2017. Holocene and Anthropocene landscapes of western Canada. In: Slaymaker O. (ed.): Landscapes and Landforms of Western Canada. Springer International Publishing, Switzerland: 49-76.

Slaymaker O, Spencer T, Dadson S. 2009. Landscape and landscape-scale processes as the unfilled niche in the global environmental change debate: an introduction. In: Slaymaker O, Spencer T, Embleton-Hamann C. (eds.): Geomorphology and Global Environmental Change. Cambridge University Press, Cambridge: 1-36.

Slaymaker O, Clague J, Gilbert R, Friele PA, Jordan P, Menounos B, Schiefer E. 2017. Lillooet-Harrison drainage basin: variable landscapes within the Coast Mountains. In: Slaymaker O. (ed.): Landscapes and Landforms of Western Canada. Springer International Publishing, Switzerland: 303-320.

Summerfield MA, Hulton NJ. 1994. Natural controls of fluvial denudation rates in major world drainage basins. Journal of Geophysical Research 99: 1387113883.

Tunnicliffe J, Church M. 2011. Scale variation of postglacial sediment yield in Chilliwack Valley, British Columbia. Earth Surface Processes and Landforms 36: 229-243.

Tunnicliffe J, Church M, Enkin RJ. 2012a. Postglacial sediment yield to Chilliwack Lake, British Columbia. Boreas 41: 84-101.

Tunnicliffe J, Church M, Clague JJ, Feathers JK. $2012 \mathrm{~b}$. Postglacial sediment budget of Chilliwack Valley, British Columbia. Earth Surface Processes and Landforms 37: 1243-1262.

Uhlmann M, Korup O, Huggel , Fischer L, Kargel JS. 2013. Supraglacial deposition and flux of catastrophic rock slope failure debris, south-central Alaska. Earth Surface Processes and Landforms 38: 675-682.

Waller RI, Murton JB, Kristensen L. 2012. Glacierpermafrost interactions: processes, products and glaciological implications. Sedimentary Geology 255256: 1-28.

Wilkinson BH, McElroy BJ. 2007. The impact of humans on continental erosion and sedimentation. Geological Society of America Bulletin 119: 140-156.

Willenbring JK, Codilean A, McElroy BJ. 2013. The Earth is mostly flat: apportionment of the flux of continental sediment over millennial time scales. Geology 41: 343-346.

Wohl E, Beckman ND. 2014. Leaky rivers: implications of the loss of longitudinal fluvial disconnectivity in headwater streams. Geomorphology 205: 27-35. 